\title{
EDITORIAL
}

\section{0: utopia and dystopia and yout(uber)ization of faculty work}

Ph.D. Hélio ARThUR Reis IRIgaray ${ }^{1}$

${ }^{1}$ Fundação Getulio Vargas (FGV EbAPE) / Brazillan School of Public and Business Administration, Rio de Janeiro - RJ, BRaZIL

When the twenty-first century was still a distant future, it was portrayed as a utopian world (as in The Jetsons). In that imaginary world, human beings would have a reduced working day and, primarily, not perform repetitive and crude tasks - which would be carried out by smart machines.

However, other creative minds imagined the twenty-first century as a dystopia (as in Mad Max and so many other movies). They portrayed a scenario of wars, epidemics, and environmental disasters.

Well, we have reached 2020. At the end of this very different and surprising year (surprising for some, since many scientists were already expecting such a scenario of a global pandemic), we are faced with a dys-utopian world, in which the Jetsons live in the world of Mad Max. A place where the cartoon's utopia - with video calls, telemedicine, freezers, microwaves, flying cars, robots - goes hand in hand with natural disasters of apocalyptic proportions. It is a world witnessing an accelerated desertification process, where hordes of desperate people (refugees, migrants, and minority groups) march aimlessly. Not to forget the plethora of zombies, i.e., beings without a minimum cognitive ability, who question science and are limited to reproducing fake news.

This collision of possible futures imagined in the last century actually happened in 2020. Over this year, the most significant challenge may have been to find meaning in our own life, an achievement that, according to Jung (2020-1972), would allow us to face anything.

In fact, giving meaning to one's own life is the only alternative to endure the pain of others' suffering, the loss of family members, friends, and millions of human beings, and face the loneliness resulting from social distancing, as well as the abrupt reconfiguration of the world of work.

In recent months, we have witnessed worsening unemployment rates, in addition to the precariousness of work itself, or, in the words of Antunes (2001, p. 6, our translation), "the dismantling of labor rights." The hijacking of workers' rights, the unilateral and unquestionable reduction of working hours and wages, the lack of safety equipment to guarantee their health and physical integrity unveiled the most perverse logic of capitalism (MACHADO, GIONGO and MENDES, 2016).

Many of these people had to become street vendors, temporary workers, self-employed. They are often described, and even glorified, as entrepreneurs, in a condition designated as the uberization of work (FONTES, 2017). "And the reality of faculty is no different".

In a televised interview before the 2020 local elections in Brazil, a politician said it was time for teachers and professors to return to work. But when did we stop working?

In record time, using technological devices and digital media, we redesigned our lessons and activities. We worked more hours than we needed to before, and we were still expected to arouse interest and promote student engagement. We live the yout(uber)ization of faculty work.

In the online lessons, we became responsible for the course content and for making sure students have their cameras on and are participating. Also, our explanations must be short and engaging to keep the audience. We are no longer just professors but also entertainers. 
The yout(uber)ization reveals an easily obscured relationship between technological development and precarious work. It is a condition that leads to physical and psychological suffering among professors.

Anxious and anguished, we were forced to develop new skills. We started to face new sources of stress (adding to stressors already known): the demand to reinvent ourselves in a short time (redesign our lessons and dynamics), the millimeter timing of our lessons, anxiety because something can go wrong (such as internet failure or power cuts), the creation of bonds with students in a virtual environment; in addition to physical pain for long hours at the computer, and the financial costs related to infrastructure (internet, electricity).

Despite all these challenges, we found time to research and produce relevant articles, such as those that make up our last issue of the year.

The first article, "Career prospects for young people in public high schools in Brazil: transgression or reproduction of social conditions?", written by Heliani Berlato, Luciano Mendes, and Danilo Andretta, analyzes the career prospects of young people in public high schools, considering social, family, educational, and cultural aspects. The authors approached the theme, adopting two perspectives: career success and career indecision.

Marcia de Freitas Duarte, in, “"The One Best Way"? Rethinking management diffusion and its impacts in decisions on academic career in the field", proposes that we rethink aspects related to the origin and diffusion of teaching and research in administration. Thus, through a confessional narrative, the process of development and legitimization of teaching and research in administration are presented, based on the literature that deals with Americanism and post-colonialism.

In, "Reinforcing the concept of social management", Fernando Guilherme Tenório and Edgilson Tavares de Araújo revisit this concept, which may be a chimera, a dream that may not come true, given the "conditions of heat and pressure" under which we live in contemporary times.

Alex Fernando Borges and Alessandro Gomes Enoque review the French entrepreneurship literature in "Entrepreneurship research: the French literature in perspective". The texts were analyzed and categorized based on the distribution of articles among the journals, the number of articles published per year, the main research topics, the type of approach, the methodological choices, and the main authors in the field. The results indicated a predominance of specific topics in French-speaking literature, such as: fostering entrepreneurship, intrapreneurship, entrepreneurial process and opportunities, female entrepreneurship, finance, entrepreneurial education, entrepreneurial profile and behavior, entrepreneurial intention, motivations for entrepreneurship, and social entrepreneurship.

"The COVID-19 pandemic and the state: is it emerging a new configuration of public administration?" by Josep Pont Vidal, discusses the consequences of the impacts caused by the COVID-19 pandemic on public administration, exploring the administration's autonomy and configuration.

In "Analysis of financial and economic feasibility of the use of vinasse for electricity generation in Brazil", Geraldo Jose Ferraresi de Araujo and Sonia Valle Walter Borges de Oliveira analyze the economic feasibility of using vinasse for electricity generation. As a specific objective, the authors identify the viable price range of $\mathrm{MWh}$ in free and regulated energy environments and plants' productive capacity for this type of investment.

Lua Syrma Zaniah Santos, Valéria Gama Fully Bressan, Vilmar Rodrigues Moreira, and Romeu Eugênio de Lima examine the relationship between credit risk and the efficiency of Brazilian credit unions from 2008 to 2017 in the article "Credit risk and technical efficiency in Brazilian credit unions".

In, "Public-private health and urban mobility partnerships in the State of Bahia: current situation, projects and main agents involved", Maina Pirajá Silva, Silvana Sá de Carvalho, and Mariana de Oliveira Santana identify the public-private partnerships (PPPs) existing in the State of Bahia, evaluate and compare their effectiveness, through case studies of health partnerships and urban mobility, by examining the structuring of projects, implementation, and operation of the concessions. They also discuss the role of public and private agents and their connections.

The article, "The Guardianship Council and public policy for children and adolescents", by Hemerson Luiz Pase, Gabriele Padilha Cunha, Marcia Leite Borges, and Ana Paula Dupuy Patella, provide an analysis of the guardianship council's role in consolidating the protection and enforcement of children and adolescents' rights in the municipality of Pelotas. 
In their work, "Challenges of federal coordination of Social Assistance Policy: the states' role in financing", Isabela de Vasconcelos Teixeira and Bruno Lazzarotti Diniz Costa analyze the degree, the variation, and the funding co-responsibility determinants of the social assistance policy by Brazilian states. The study verified the contribution of federative coordination and induction mechanisms, pointed out by several authors as a success factor.

Fabiana Tock, Eduardo José Grin, and Lauro Gonzalez seek to explain how the combination of the institutional characteristics of SUAS and the structural, institutional, and political conditions regulate or enable the creation of state capacities. The results of their article, "The Brazilian states and the Federal Social Assistance System: state capacity-building in Maranhão and São Paulo", point out that such conditions were decisive in capacity building and, above all, inform the role assumed by the state government in SUAS.

In, "Noiva do Cordeiro community: contributions from elements of a system based on substantive economy", Luiz Paulo Rigueira de Morais, Wescley Silva Xavier, and Daniel Calbino Pinheiro investigate how the formation and interaction of an alternative economic system occurred in the community of Noiva do Cordeiro-MG with the dynamics of the mercantile economy.

Gustavo Henrique Carvalho de Castro and Marcus Vinicius Soares Siqueira, in, “"They'll think it's a joke, but for us, it is not!": speeches of resistance from Brazilian gay soccer clubs", discuss discrimination against homosexuals, perpetrated by homophobic injury, performative speech acts that silence and alienate gay individuals, reinforcing the cult of hegemonic masculinity.

In, "Women in politics: emotions and challenges in complex institutional dynamics", Camilla Fernandes, Mariane Lemos Lourenço, Samantha Frohlich, Diogo Espejo da Silva, and Flávia Obara Kai explore the role of emotions in institutional dynamics, especially regarding women's political participation in Brazilian 2018 general elections.

Finally, the theoretical essay, "From the sacred to the profane: connections between Christian theology and administration", by Aline Van Neutgem and Eloise Helena Livramento Dellagnelo, make connections between Christian theology and administration.

I wish you a pleasant read!

Hélio Arthur Reis Irigaray

Editor-in-chief 


\section{REFERENCES}

ABÍLIO, L. C. A 'uberização' e as encruzilhadas do mundo do trabalho. IHU On-Line - Revista do Instituto Humanitas Unisinos, ano 15, n. 503, p. 2, abr. 2017. Available at: <http://www.ihuonline.unisinos. br/media/pdf/IHUOnlineEdicao503.pdf>. Accessed on: Dec. 03, 2019.

ANTUNES, R. Os sentidos do trabalho: ensaio sobre a afirmação e negação do trabalho. 6. reimp. São Paulo: Boitempo Editorial, 2003.

FONTES, V. Capitalismo em tempos de uberização: do emprego ao trabalho. Marx e o Marxismo-Revista do NIEP-Marx, v. 5, n. 8, p. 45-67, 2017.
JUNG, C. G. Collected works of C. G. Jung. Volume 7: Two Essays in Analytical Psychology. 2. ed. Kindle Edition. Princeton: Princeton University Press, 2020-1972.

MACHADO, F. K. S.; GIONGO, C. R.; MENDES, J. M. R. Terceirização e precarização do trabalho: uma questão de sofrimento social. Revista Psicologia Política, v. 16, n. 36, p. 227-240, 2016. 